\title{
Effect of Dietary Tryptophan Supplementation on Uterine Morphology in Layer Chicken
}

\author{
Manju G. Preedaa ${ }^{1 *}$, P. Selvaraj ${ }^{1}$, P. Visha $^{1}$, K. Balasundaram ${ }^{2}$, \\ M.R. Purushothaman ${ }^{3}$ and N. Murali ${ }^{4}$
}

\author{
${ }^{1}$ Department of Veterinary Physiology, ${ }^{2}$ Department of Veterinary Anatomy, \\ ${ }^{3}$ Department of Animal Nutrition, ${ }^{4}$ Department of Animal Genetics and Breeding, Veterinary \\ College and Research Institute, Tamil Nadu Veterinary and Animal Sciences University \\ (TANUVAS), Namakkal, India
}

*Corresponding author

\begin{abstract}
A B S T R A C T
The study was conducted to ascertain the effect of supplemental tryptophan on uterine histomorphological structures of white Leghorn layers. A total of 350 White Leghorn

Keywords

Layers, Tryptophan, Uterus and $\mathrm{H} \& \mathrm{E}$

\section{Article Info}

Accepted: 06 August 2018 Available Online: 10 September 2018 layers of 18 weeks were allocated to seven experimental groups, each of which included 5 replicates and reared upto 45 weeks of age. Experimental diets consisted of two protein diets along with 5 supplemental levels of tryptophan. The basal diet consisted of normal protein (CP-17\%) with $0.165 \%$ tryptophan and low protein diet with $0.153 \%$ tryptophan. Tryptophan was supplemented at $0.012,0.015$ and $0.035 \%$ in normal protein diet to obtain $0.165 \%, 0.18 \%$ and $0.20 \%$ digestible tryptophan and at $0.027 \%, 0.047 \%$ in low protein diets (CP- $16.23 \%$ ) to obtain $0.18 \%$ and $0.20 \%$ digestible tryptophan respectively. At the end of the study, oviducts from six birds per treatment were dissected out and gross morphometrical parameters like length and weight were recorded. For histological studies, after tissue preparation and staining with $H \& E$, histological layer of uterus was studied. Our data analysis indicated that the total weight and length of various segments of oviduct did not differ by tryptophan supplementation. The histological layers of uterus were also not altered by tryptophan supplementation.
\end{abstract}

\section{Introduction}

Reproduction in poultry is completely different from other farm animal species. In poultry, there are two principle reproductive organs; ovary and oviduct; which participate in the production of eggs in laying hen. The oviduct of chicken is an egg producing organ, which convey the ovum to the cloaca and it successively adds the albumin from the glands of magnum. Finally, shell membrane is added from isthmus, the hard calcite shells and shell 
pigments from uterus and the bloom or cuticle from the gland of vagina. Thus, oviduct play vital role in the assembly of egg components after receiving ova from ovary.

Any alteration or deviation in the function of the oviduct of a laying hen can directly affect egg and egg shell quality. Decline in egg and egg shell quality costs the egg industry millions of dollars every year.

The increase of digestible tryptophan: digestible lysine ratio favoured the number of secondary folds in the uterus of layers resulting in higher production of mucus and albumen in the magnum. This leads to reduction in the egg formation time thus increasing production, weight, mass, conversion in mass and egg dozens (Lima et al., 2012). The present investigation was conducted to study the anatomy and the histological features of uterus in layer hens due to tryptophan supplementation.

\section{Materials and Methods}

Three hundred and fifty Single Comb White Leghorn layers of 16 weeks were procured from commercial breeding farm (Namakkal) and the experiment was conducted from March to October 2016 at Veterinary College and Research Institute, Namakkal, Tamil Nadu.

At the age of 18 weeks, after two weeks of adaptation the layer birds were divided into seven treatments with five replicates per treatment and each replicate had 10 birds. The layers were reared in cages in gable roofed open sided, elevated platform house. All the birds were provided with uniform cage floor, feeder and water space and were reared under standard management conditions throughout the experimental period. Birds were vaccinated against Ranikhet disease (RDVF1) and Infectious Bronchitis (IB).
The experimental layer diets were formulated according to the breeder's specification (Venkateshwara Hatcheries Private Limited). In commercial formulation, the levels of essential amino acids were fixed in relationship with lysine, however in our experiment the essential amino acids were fixed based on digestible tryptophan.

Diet I (T1) was formulated with 17 per cent protein (normal) as followed in commercial layer farms with the digestible tryptophan of $0.165 \%$. Diet II (T2) was formulated with $0.153 \%$ digestible tryptophan, meeting requirements of other essential amino acids as per breeder's specification with low protein $(16.23 \%)$.

Diet III (T3) was formulated to meet out the difference in digestible tryptophan between diet I and II by supplementing digestible tryptophan at the level of $0.012 \%$ to basal diet II. Diet IV (T4) and V (T5) were formulated by supplementing $0.015 \%$ and $0.035 \%$ tryptophan to diet I to attain $0.18 \%$ and 0.20 $\%$ digestible tryptophan levels respectively. Diet VI (T6) and VII (T7) were formulated by supplementing $0.027 \%$ and $0.047 \%$ tryptophan to diet II to attain $0.18 \%$ and $0.20 \%$ digestible tryptophan levels respectively.

The ingredients of the diets are presented in the Table 1.

At the end of the experiment $\left(45^{\text {th }}\right.$ week), six birds per treatment were randomly selected and slaughtered. The whole oviduct was quickly dissected out and stretched on a paper. The length $(\mathrm{cm})$ of the oviduct was measured and weighed. The morphological parameters like total length and weight of oviduct, individual length of various segments of oviduct were recorded by caliper device. For histological observations, uterus of the oviduct was separated by incision and fixed in Bouins 
fluid and processed for routine microtome. After tissue preparation and staining with $\mathrm{H}$ and E as per Bancroft and Stevens (1996), histological layers of uterus such as tunica mucosa, submucosa and muscularis were recognized and the primary fold length of tunica mucosa were measured using micrometry method. Photographs of the prepared slides were taken with microscope equipped with a camera (Zeiss primostar, Germany with Axiocam ERC5S camera).

\section{Results and Discussion}

The effect of supplementation of tryptophan on morphometrical parameters of oviduct and primary fold length of uterus are presented in Table 2 and 3.

The gross morphology of oviduct including infundibulum, magnum, isthmus, uterus and vagina of layer chicken showed normal morphometry. The mean length $(\mathrm{cm})$ of infundibulum, magnum, isthmus, uterus, vagina, total oviduct and the mean total oviductal weight (g) among all the birds were in normal range and agree with report by Mohammadpour et al., (2012) in 12-18 months and Mishra et al., (2014) in 8-11 months old layer birds. No change in length of infundibulum, magnum, isthmus, uterus and vagina and total oviduct weight.

The histology of uterus of layer chicken showed normal histological structures (Plate $1)$. The mean lengths of primary folds $(\mu \mathrm{m})$ of uterus in our study were in normal range of $1367.8 \pm 3.0$ to $1396.7 \pm 2.6$ and our findings are in agreement to Mohammadpour et al., (2012) in 12-18 months layers.

In our study tryptophan supplementation till $45^{\text {th }}$ week of age in layers had no influence in primary fold length of uterus.

Table.1 Ingredients composition (\%) of pre-layer and layer diet fed different levels of tryptophan and crude protein

\begin{tabular}{|c|c|c|c|c|}
\hline Ingredients (\%) & \multicolumn{2}{|c|}{ Pre-layer diet } & \multicolumn{2}{|c|}{ Layer diet } \\
\cline { 1 - 3 } & $\begin{array}{c}\text { Diet I } \\
\text { (normal } \\
\text { protein) }\end{array}$ & $\begin{array}{c}\text { Diet II } \\
\text { (low protein) }\end{array}$ & $\begin{array}{c}\text { Diet I } \\
\text { (normal } \\
\text { protein) }\end{array}$ & $\begin{array}{c}\text { Diet II } \\
\text { (low protein) }\end{array}$ \\
\hline Maize & 50.8 & 52.5 & 49.6 & 52.2 \\
\hline Deoiled rice bran & 15.0 & 15.0 & 15.0 & 15.0 \\
\hline Sunflower oil cake & 8.9 & 10.0 & 5.1 & 4.3 \\
\hline Soyabean meal & 15.6 & 12.4 & 16.5 & 14.7 \\
\hline Fish meal & 3.0 & 3.0 & 3.1 & 3.2 \\
\hline Di calcium phosphate & 0.7 & 0.7 & 0.56 & 0.58 \\
\hline Calcite & 4.0 & 4.0 & 4.0 & 4.0 \\
\hline Shell grit & 1.8 & 2.0 & 5.7 & 5.7 \\
\hline DL-Methionine & 89 & 96 & 141 & 165 \\
\hline (g/100kg) & 8 & 87 & 0 & 34 \\
\hline Lysine (g/100kg) & 0 & 0 & 34 & 62 \\
\hline L-Threonine (g/100kg) & 0 & 27 & 55 & 61 \\
\hline SodaBicarb (g/100kg) & 33 & & & \\
\hline
\end{tabular}


Table.2 Mean ( \pm SE) morphometrical parameters of oviduct in White Leghorn layers fed different levels of tryptophan and crude

\begin{tabular}{|c|c|c|c|c|c|c|c|}
\hline Treatment & $\begin{array}{c}\text { Infundibulum } \\
\text { length }(\mathbf{c m})\end{array}$ & $\begin{array}{c}\text { Magnum } \\
\text { length }(\mathbf{c m})\end{array}$ & $\begin{array}{c}\text { Isthmus } \\
\text { length }(\mathbf{c m})\end{array}$ & $\begin{array}{c}\text { Uterus } \\
\text { length }(\mathbf{c m})\end{array}$ & $\begin{array}{c}\text { Vagina } \\
\text { length } \mathbf{( c m )}\end{array}$ & $\begin{array}{c}\text { Total length } \\
(\mathbf{c m})\end{array}$ & $\begin{array}{c}\text { Total weight } \\
(\mathbf{g})\end{array}$ \\
\hline T1 & $11.2 \pm 0.6$ & $32.1 \pm 0.5$ & $14.5 \pm 0.4$ & $7.2 \pm 0.2$ & $6.3 \pm 0.1$ & 71.3 \\
\hline T2 & $11.0 \pm 0.5$ & $32.3 \pm 0.4$ & $14.5 \pm 0.4$ & $7.1 \pm 0.2$ & $6.2 \pm 0.1$ & 71.1 & $51.9 \pm 0.6$ \\
\hline T3 & $11.2 \pm 0.6$ & $32.3 \pm 1.4$ & $14.4 \pm 0.3$ & $7.2 \pm 0.2$ & $6.3 \pm 0.3$ & 71.4 & $52.0 \pm 0.1$ \\
\hline T4 & $11.4 \pm 0.6$ & $32.5 \pm 1.1$ & $14.7 \pm 0.4$ & $7.5 \pm 0.1$ & $6.2 \pm 0.3$ & 72.3 & $53.3 \pm 0.7$ \\
\hline T5 & $11.2 \pm 0.5$ & $32.2 \pm 0.3$ & $14.9 \pm 1.1$ & $7.5 \pm 0.1$ & $6.4 \pm 0.2$ & 72.2 & $53.9 \pm 0.1$ \\
\hline T6 & $11.6 \pm 0.6$ & $32.5 \pm 0.9$ & $14.8 \pm 0.7$ & $7.3 \pm 0.3$ & $6.3 \pm 0.4$ & 72.5 \\
\hline T7 & $11.5 \pm 1.1$ & $32.2 \pm 0.7$ & $14.7 \pm 0.5$ & $7.5 \pm 0.2$ & $6.3 \pm 0.3$ & 72.2 \\
\hline
\end{tabular}

Table.3 Mean $( \pm$ SE) primary fold heights $(\mu \mathrm{m})$ of uterus in White Leghorn layers fed different levels of tryptophan and crude

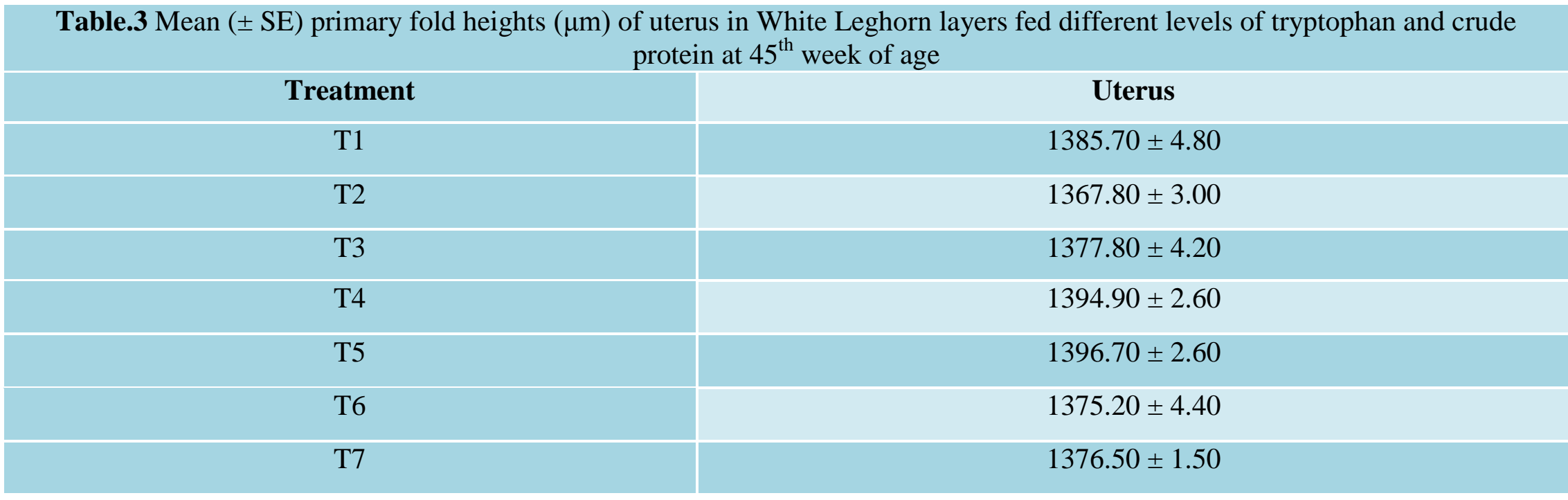


The experimental groups and their diets are as follows

\begin{tabular}{|l|l|l|l|l|}
\hline Treatment & Diets & $\begin{array}{l}\text { No of } \\
\text { birds }\end{array}$ & $\begin{array}{l}\text { No } \\
\text { replicates }\end{array}$ & $\begin{array}{l}\text { No of birds I } \\
\text { replicates }\end{array}$ \\
\hline Diet I $\left(\mathrm{T}_{1}\right)$ & $\begin{array}{l}\text { Layer diet with 17 \% CP and } \\
\text { 0.165\% digestible tryptophan }\end{array}$ & 50 & 5 & 10 \\
\hline Diet II $\left(\mathrm{T}_{2}\right)$ & $\begin{array}{l}\text { Layer diet with 16.23\% CP and } \\
\text { 0.153\% digestible tryptophan }\end{array}$ & 50 & 10 \\
\hline Diet III $\left(\mathrm{T}_{3}\right)$ & $\begin{array}{l}\text { Diet II+ 0.012 \% digestible } \\
\text { tryptophan supplementation }\end{array}$ & 50 & 5 & 10 \\
\hline Diet IV $\left(\mathrm{T}_{4}\right)$ & $\begin{array}{l}\text { Diet I+ 0.015 \% digestible } \\
\text { tryptophan supplementation }\end{array}$ & 50 & 10 \\
\hline Diet V $\left(\mathrm{T}_{5}\right)$ & $\begin{array}{l}\text { Diet I+ 0.035 \% digestible } \\
\text { tryptophan supplementation }\end{array}$ & 50 & 5 & 10 \\
\hline Diet VI $\left(\mathrm{T}_{6}\right)$ & $\begin{array}{l}\text { Diet II+ 0.027 \% digestible } \\
\text { tryptophan supplementation }\end{array}$ & 50 & 5 & 10 \\
\hline Diet VII $\left(\mathrm{T}_{7}\right)$ & $\begin{array}{l}\text { Diet II+ 0.047 \% digestible } \\
\text { tryptophan supplementation }\end{array}$ & 50 & 5 & 10 \\
\hline
\end{tabular}

Plate.1 Primary fold heights $(\mu \mathrm{m})$ of uterus in White Leghorn layers fed different levels of tryptophan and crude protein at the age of 45 weeks ( $H \& E$ x 40)

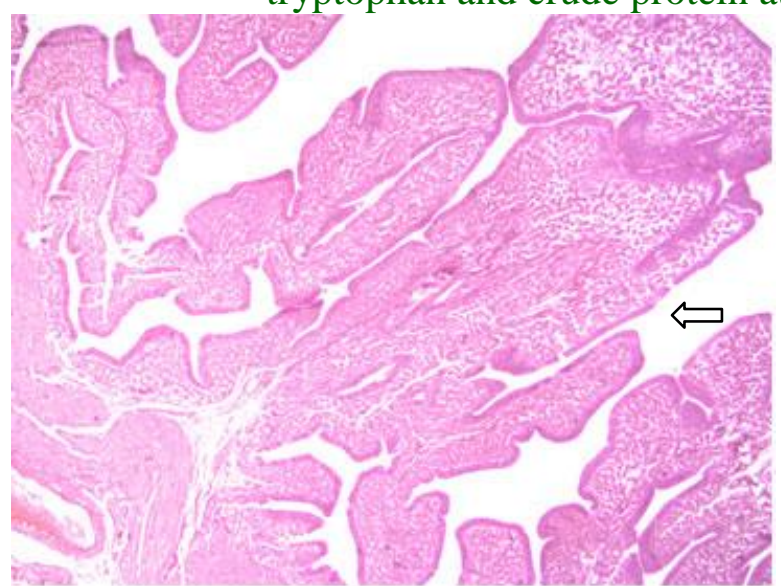

T1 (17.00 \% CP with $0.165 \%$ tryptophan)

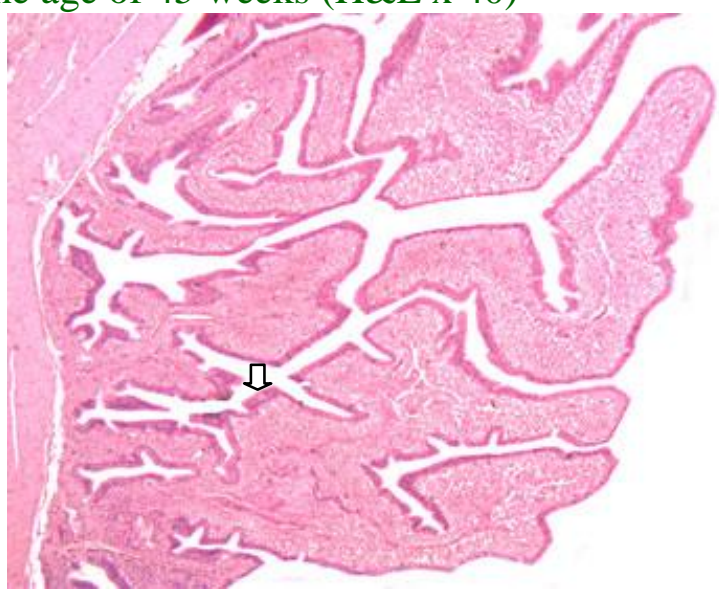

T2 (16.23 \% CP with $0.153 \%$ tryptophan)

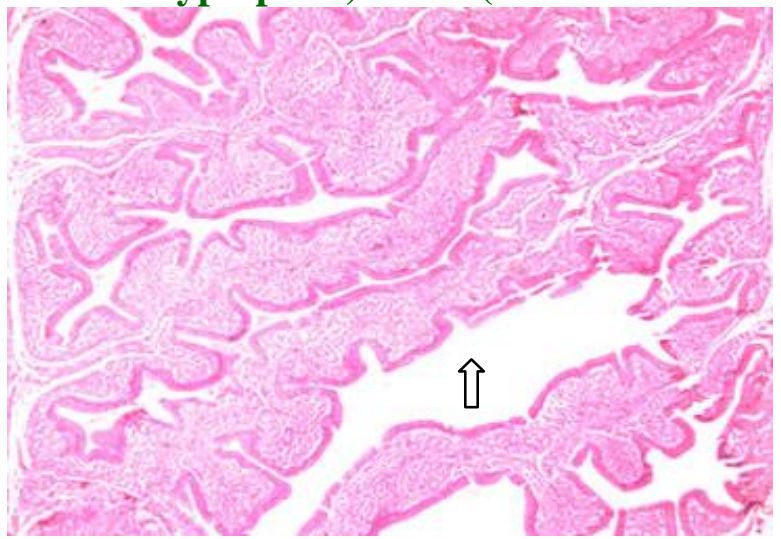

T4 (17.00\% CP with $0.18 \%$ tryptophan) 


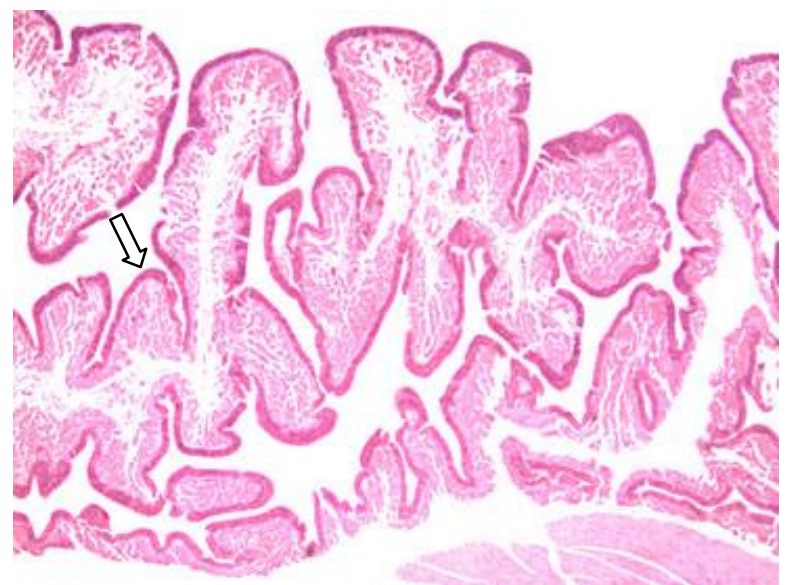

T5 (17.00 \% CP with $0.20 \%$ tryptophan)

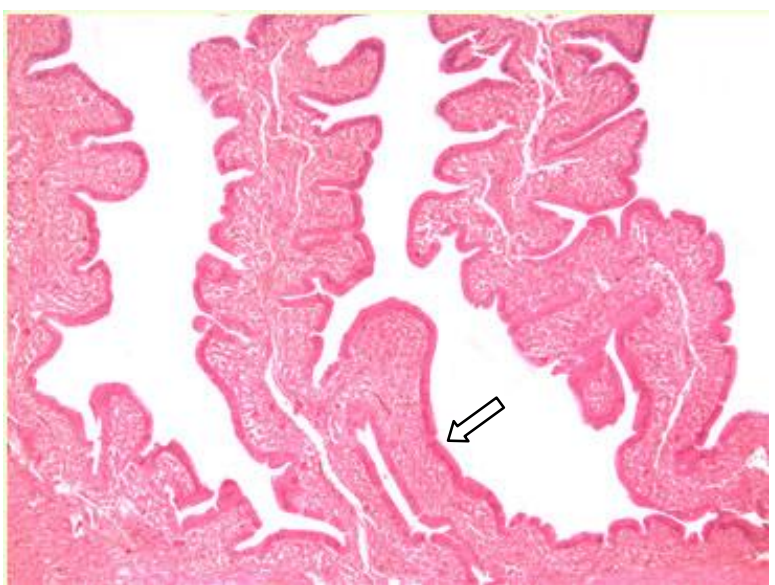

T6 (16.23 \% CP with $0.18 \%$ tryptophan)

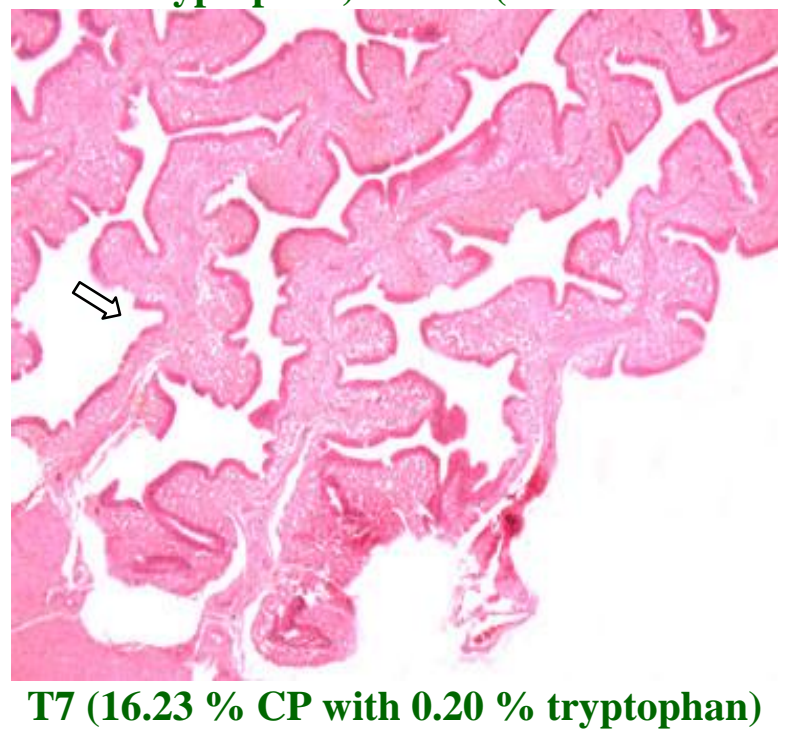

Our findings were contrary to Lima et al., (2012) who observed increased uterine folds in laying hens supplemented with tryptophan at $0.183,0.199$ and $0.215 \%$.

The histomorphological results indicated that tryptophan supplementation did not cause any histological changes in uterus of layer hens.

\section{Acknowledgement}

The authors wish to thank the Dean, Veterinary College and Research Institute, Namakkal and Tamilnadu Veterinary and Animal Sciences University for providing necessary funds and research facilities to carry out the study.

\section{References}

Bancroft, J.D. and Stevens, A. 1996. Theory and practice of histological techniques. $4^{\text {th }}$ Edn. Churchill Livingstone, London.

Lima, M.R., Costa, F.G., Guerra, R.R., Silva, J.H.V., Rabello, C.B., Miglino, M..A, Nogueira, E.T. and Pinheiro, G.S. 2012. Digestible tryptophan: lysine ratio for laying hens. Revista Brasileria de Zootechnia. 41(10): 2203-2210.

Mishra, D., Sultana, N., Masum, M.A. and Rahman, S. 2014. Gross and histomorphological studies of the oviduct of native chicken of Bangladesh. Bangladesh Journal of Veterinary Medicine. 12(1): 9-15. 
Mohammadpour, A.A., Abdolkarim, Z. and Massoumeh, H. 2012. Comparative histomorphometrical study of genital tract in adult laying hen and duck. Veterinary Research Forum. 3(1): 2730.

\section{How to cite this article:}

Manju G. Preedaa, P. Selvaraj, P. Visha, K. Balasundaram, M.R. Purushothaman and Murali, N. 2018. Effect of Dietary Tryptophan Supplementation on Uterine Morphology in Layer Chicken. Int.J.Curr.Microbiol.App.Sci. 7(09): 600-606. doi: https://doi.org/10.20546/ijcmas.2018.709.071 